\title{
BIOCHEMICAL IMPACTS OF VARIOUS COMPOUNDS ON THE TWO LAND SNAILS SPECIES, Eobania vermiculata AND Monacha obstructa.
}

(Received: 26. 1.2014)

\author{
By \\ S. A. Mobarak \\ Plant Protection Research Institute, Agriculture Research Center, Giza, Egypt.
}

\begin{abstract}
The biochemical impacts of five chemical compounds i.e., pesticide formulation ( methomyl, lambada- cyhalothrin, thiamethoxame), biobesticide (spinosad) and Tannic acid (as a natural product, polyphenols) were studied against two land snail species, Eobania vermiculata and Monacha obstructa using the bait technique. The effect of $\mathrm{LC}_{50}$ of each compound was determined on some biochemical parameters (alkaline (ALP) and acid (ACP))phosphatase activities, total protein, total lipid and cholesterol content) which are important for shell production of the snails.

The different parameters were measured after 1, 3 and 7 days of administration. The results showed that all compounds caused fluctuated effect between decrease and increase for the two snail species. The influence of methomyl and tannic acid came in the first or the second rank on ACP and ALP activities as well as cholesterol content, while the rest compounds showed different effects on the biochemical parameters of the two snail species. Tannic acid exhibited a strong effect on all biochemical parameters which are responsible for the production of the shell, without it the snail dies. Therefore, tannic acid, as a natural product, can be used in the control programs of terrestrial snails.
\end{abstract}

Key words: biochemical impacts, land snails, tannic acid, pesticides.

\section{INTRODUCTION}

The terrestrial mollusks are considered major pests of a wide range of agricultural and horticultural crops in temperate and humid habitats worldwide. These animals. Attack different kinds of plants (eg., cereals, vegetables, fruit orchards and ornamental plants) at different growth stages, reducing their yields. The chocolate band snail Eobania vermiculata and the glassy clover snail Monacha obstructa are considered the most common and harmful species in several governorates in Egypt (Eshra 2013). Recently, much efforts have been directed towards screening and evaluation of chemicals to control land snails specially against their shell (the first line of defence).

The present study was conducted to investigate the molluscicitial activity and biochemical effect of certain synthetic and bio pesticides and tannic acid as a natural product. This, is an attempt to reduce the secretion and weakening the shell structure by using pesticides against two land snail species.

Therefore the impact of the tested compounds on some biochemical parameters of the snails, i.e. Alkaline and acid phosphatase activity, total protein total lipid and cholesterol content which play an important role in the synthesis of the shell in the mantel were studied.

\section{MATERIALS AND METHODS}

\subsection{Tested compounds}

Different types of chemicals were used. These chemicals are compiled as follows:

\subsubsection{Synthetic compounds}

\subsubsection{Methomyl}

Newmyl ( $20 \%$ SL) carbamate compound was obtained from KZ. Pesticides company, Egypt.

\subsubsection{Lambada- Cyhalothrin}

Lampada (10\% CS) pyrethroid compound. was supplied by Syngenta CO.

\subsubsection{Thiamethoxame}

Actra (25\% WG), was supplied by Syngenta CO.

\subsubsection{Bioinsecticides \\ 2.1.2.1. Spinosad}

Tracer (24\% SC), produced by fermentation of soil microorganism actinomycete, Sccharopolyspoea spinosa. It was obtained from Dow Agro Scieneces CO., Egypt. 


\subsubsection{Natural compound}

2.1.3.1.Tannic acid (100\% Powder) was supplied by Oxford CO.

\section{2. Tested animals}

Four-month old laboratory reared individuals of two land snail, Eobania vermiculata, and the glassy clover snail, Monacha obstructa, were used. Animals were reared in plastic boxes containing 10 $\mathrm{cm}$ moist soil, clay, peat and sand (1:1:1) and covered with rubber band to prevent snails from escaping. Animals were fed on carrots and lettuce (Godan, 1983). They were adapted to the experimental conditions and finally starved for the last $24 \mathrm{~h}$ during adaptation. Ten animals for each species were used for each test.

\subsection{Baiting technique}

The tested compounds were applied as poison bait. Poison bait was prepared by incorporating $\mathrm{LC}_{50}$ in $\mathrm{mg} / \mathrm{kg}$ for each compound and added to wheat bran to give 100 parts of poison bait as follows: Methomyl $(0.18,0.16)$, L-Cyhalothrin $(1.06,1.38)$, Thiamethoxam (1.23, 1.78), Spinosad (9.00, 6.13), and tannic acid (24.13, 23.79) for Eobania vermiculata and Monacha obstructa, respectively according to (Kandil et al., 2007).

Ten grams of poison bait were spread into each plastic box for each compound. Three replicates were used for each treatment. Control test was run using wheat bran free chemical. Animals were exposed to bait for $72 \mathrm{~h}$.

\subsection{Biochemical studies}

Effect of $\mathrm{LC}_{50}$ of each tested compound on certain enzyme activities and biochemical parameters were determined to clarify the physiological impact on the two land snail species. Alkaline phosphatase, acid phosphatase activity, total protein, total lipid, and cholesterol content were measured at different intervals 1, 3 and 7 days after the treatment. A parallel control test was conducted.

\subsubsection{Sample preparation}

Ten animals of each land snail species, Eobania vermiculata and Monacha obstructa at $1 \mathrm{~g}$ weight were homogenized under cooling in a homogenizer for 3 minutes with $10 \mathrm{ml}$ of 0.006 $\mathrm{M}$ phosphate buffer, $\mathrm{pH}=7$, at $1-4^{\circ} \mathrm{C}$, and centrifuged (3500 r.p.m.) for $10 \mathrm{~min}$. The following procedure was used according to Bergmeyer (1963). The sediment was stirred with cold phosphate buffer $0.006 \mathrm{M}$ and allowed to stand in the ice bath with shaking. The extraction process was repeated twice. The whole extract sample was cleaned through centrifugation several times. The extraction process takes not more than 24 hours under cooling conditions in the refrigerator.

\subsubsection{Determination of Alkaline and acid} phosphatase

The method described by Kind and King (1954) was utilized.

\subsubsection{Determination of total protein}

Spectrophotometrically method of soluble protein was conducted according to Henry (1964) using Buiret reagent.

\subsubsection{Determination of total Lipid}

Lipid content were measured spectophotometrically according to Zollner Kirsch (1962).

\subsubsection{Determination of cholesterol}

The spectophotometric determination of cholesterol content was carried out according to Ellefson and Caraway (1976).

The obtained results were statistically analyzed by one way ANOVA and Least Significant Difference (LSD) at $(\mathrm{p} \leq 0.05)$ using Costat program (COHORT, 2005)

\section{RESULTS AND DISCUSSION}

\section{1. Effect on Alkaline phosphatase (ALP)}

Akaline phosphatase plays an important role in the active transport of chemicals across cell membranes through the process of phosphorylation of carbohydrates and fats (Hugon and Bogres, 1996).

The data in Table (1) show the effect of $\mathrm{LC}_{50}$ of the tested compounds as bait comparing with methomyl formulation (the recommended compound) on alkaline phosphatase activity in both land snail species after three different periods. The results indicate that methomyl formulation enhanced ALP activity sharply 1-day after the treatment $(884.8 \mathrm{u} / \mathrm{l})$. With time elapsed the enzyme activity decreased to 552.0 and 375.7 after 3 and 7 days of the treatment comparing with the control $233.6 \mathrm{u} / \mathrm{l}$ for Eobania. vermiculata. Concerning Monacha obstructa the methomyl formulation reduced the enzyme activity proportionally to $455.7 \mathrm{u} / \mathrm{l}$ and it raised again to 845.4 after 1 and 3 days, respectively while it decreased to $365.0 \mathrm{u} / 1$ on the $7^{\text {th }}$ day comparing with $526.0 \mathrm{u} / 1$ for the control. Lambada cyhalothrin formulation treatment increased ALP activity to $256.6 \mathrm{u} / \mathrm{l}$ after the first day of treatment for E. vermiculata while this value decreased to 124.9 for the third day and it raised to reach $204.5 \mathrm{u} / \mathrm{l}$ but still lower than the control level (233.6) after 7 days of treatment. Vice versa occurred with $M$. obstructa the enzyme activity decreased gradually to 435.4 , 
Table (1): Effect of $\mathrm{LC}_{50}(\mathrm{mg} / \mathrm{kg})$ of various compounds used as bait on alkaline phosphatase $(\mu / \mathrm{l})$ in two land snail species.

\begin{tabular}{|c|c|c|c|c|c|c|c|c|}
\hline \multirow{3}{*}{ Compounds } & \multicolumn{4}{|c|}{ Eobania vermiculata } & \multicolumn{4}{|c|}{ Monacha obstructa } \\
\hline & \multicolumn{4}{|c|}{ Periods after treatment (days) } & \multicolumn{4}{|c|}{ Periods after treatment (days) } \\
\hline & $\mathbf{0}$ & $\mathbf{1}$ & 3 & 7 & $\mathbf{0}$ & $\mathbf{1}$ & 3 & 7 \\
\hline Methomyl & $233.6 \pm 0.02$ & $884.8 \pm 1.3$ & $552.0 \pm 0.2$ & $375.7 \pm 0.5$ & $526.0 \pm 0.01$ & $455.7 \pm 1.4$ & $845.4 \pm 1.4$ & $365.0 \pm 0.3$ \\
\hline L- cyhalothrin & $233.6 \pm 0.02$ & $256.6 \pm 1.2$ & $124.9 \pm 4.0$ & $204.5 \pm 1.2$ & $526.0 \pm 0.01$ & $435.4 \pm 2.2$ & $275.1 \pm 6.0$ & $135.1 \pm 0.0$ \\
\hline Thiamethoxam & $233.6 \pm 0.02$ & $264.5 \pm 0.9$ & $244.5 \pm 1.9$ & $277.5 \pm 2.0$ & $526.0 \pm 0.01$ & $583.8 \pm 3.7$ & $162.4 \pm 6.2$ & $376.2 \pm 3.0$ \\
\hline Spinosad & $233.6 \pm 0.02$ & $449.9 \pm 1.4$ & $139.9 \pm 2.4$ & $415.7 \pm 0.3$ & $526.0 \pm 0.01$ & $472.0 \pm 3.0$ & $452.0 \pm 3.3$ & $609.3 \pm 5.5$ \\
\hline Tannic acid & $233.6 \pm 0.02$ & $67.5 \pm 5.0$ & $45.40 \pm 1.5$ & $145.4 \pm 2.3$ & $526.0 \pm 0.01$ & $156.0 \pm 1.0$ & $239.3 \pm 1.7$ & $157.5 \pm 1.9$ \\
\hline LSD & 0.02 & 13.3 & 191.3 & 6.03 & 0.02 & 5.0 & 47.8 & 7.8 \\
\hline
\end{tabular}

275.1 and $135.1 \mathrm{u} / \mathrm{l}$ after 1,3 and 7 days of Lcyhalothrin formulation treatment comparing with $526.0 \mathrm{u} / \mathrm{l}$ for the control. Opposite effect was observed with thiamethoxam formulation in the case of E. vermiculata which increased to 264.5 after the first day of treatment and decreased to 244.5 after 3 days but it elevated again to $277.5 \mathrm{u} / \mathrm{l}$ after 7 days of treatment comparing with the control level $(233.6 \mathrm{u} / \mathrm{l})$. Thiamethoxam took the same trend with $M$. obstructa where the enzyme activity fluctuated between stimulation and inhibition. It increased to $110 \%$ after 1 day of administration, then decreased to $30 \%$ after 3 days of the treatment while it reached to $71 \%$ after 7 days. Spinosad formulation treatment followed the same trend where it raised the enzyme activity to $192 \%$ then inhibited it to $60 \%$ while it caused higher increase in the enzyme activity to $178 \%$ after 1 , 3 and 7 days, respectively for E. vermiculata comparing with the control. On the other hand, spinosad formulation treatment took another pattern in the case of $M$. obstructa where the activity decreased the enzyme activity from $526.0 \mathrm{u} / \mathrm{l}$ in the control to 472.0 and $452 \mathrm{u} / \mathrm{l}$ after the $1^{\text {st }}$ and the $3^{\text {rd }}$ days, consecutively. While it increased again to $609.3 \mathrm{u} / 1$ higher than the control value. Inhibition occurred in the enzyme activity to 67.5 and 45.4 after 1 and 3 days consecutively in the case of tannic acid treatment but the enzyme activity increased to $145.4 \mathrm{u} / \mathrm{l}$ in the 7 day but it still lower than normal activity $233.6 \mathrm{u} / \mathrm{l}$ of the control. The same trend occurred in the case of $M$. obstructa where the enzyme activity decreased to $29.6 \%$ of the control after 1 day of the treatment while it raised to $45.4 \%$ after 3 days and reduced again to $29.9 \%$ after 7 days of administration.

\subsection{Effect on acid phosphatase (ACP)}

Acid phosphatase is a lysosomal enzyme and plays an important role in catabolism, pathological necrosis, autolysis and phagocytosis (Singh and Agarwal, 1992).

The data in Table (2) show that methomyl formulation treatment caused a sharp decrease in the acid phosphatase activity for E. vermiculata in the three periods. It reduced the enzyme activity to about $16 \%, 17 \%$, and $9.5 \%$ of the control after 1,3 and 7 days after treatment, respectively. The same results occurred in the case of $M$. obstructa where the enzyme activity was decreased to $12 \%, 7 \%$ and increased to $9 \%$ after 1,3 and 7 days of the control activity. Lcyhalothrin formulation treatment decreased the enzyme activity after the first day of the treatment from $3.89 \mathrm{u} / \mathrm{l}$ of the control to $2.42 \mathrm{u} / \mathrm{l}$

Table (2): Effect of $\mathrm{LC}_{50}(\mathrm{mg} / \mathrm{kg})$ of various compounds used as bait on acid phosphatase $(\mu / \mathrm{l})$ in two land snail species.

\begin{tabular}{|c|c|c|c|c|c|c|c|c|}
\hline \multirow{3}{*}{ Compounds } & \multicolumn{4}{|c|}{ Eobania vermiculata } & \multicolumn{4}{|c|}{ Monacha obstructa } \\
\hline & \multicolumn{4}{|c|}{ Periods after treatment (days) } & \multicolumn{4}{|c|}{ Periods after treatment (days) } \\
\hline & $\mathbf{0}$ & 1 & 3 & 7 & $\mathbf{0}$ & 1 & 3 & 7 \\
\hline Methomyl & $3.89 \pm 0.06$ & $0.62 \pm 0.01$ & $0.66 \pm 0.03$ & $0.37 \pm 0.02$ & $3.59 \pm 0.01$ & $0.44 \pm 0.3$ & $0.24 \pm 0.5$ & $0.29 \pm 0.04$ \\
\hline L- cyhalothrin & $3.89 \pm 0.06$ & $2.42 \pm 0.2$ & $3.28 \pm 0.1$ & $5.75 \pm 0.1$ & $3.59 \pm 0.01$ & $5.90 \pm 0.1$ & $20.47 \pm 1.9$ & $11.33 \pm 1.7$ \\
\hline Thiamethoxam & $3.89 \pm 0.06$ & $3.38 \pm 0.3$ & $3.07 \pm 0.3$ & $8.27 \pm 0.2$ & $3.59 \pm 0.01$ & $2.42 \pm 0.0$ & $6.91 \pm 6.5$ & $11.05 \pm 1.0$ \\
\hline Spinosad & $3.89 \pm 0.06$ & $5.39 \pm 0.3$ & $6.48 \pm 0.05$ & $9.59 \pm 0.06$ & $3.59 \pm 0.01$ & $3.59 \pm 1.05$ & $2.27 \pm 2.0$ & $10.39 \pm 0.8$ \\
\hline Tannic acid & $3.89 \pm 0.06$ & $5.05 \pm 0.0$ & $5.72 \pm 0.1$ & $4.69 \pm 0.04$ & $3.59 \pm 0.01$ & $6.72 \pm 1.5$ & $6.37 \pm 0.7$ & $3.99 \pm 3.0$ \\
\hline LSD & 0.02 & 0.33 & 0.23 & 0.50 & 0.02 & 5.00 & 47.87 & 7.83 \\
\hline
\end{tabular}


but it was increased gradually after 3 and 7 days after the treatment to 3.28 and $5.75 \mathrm{u} / \mathrm{l}$ comparing with the control value of $E$. vermiculata. While it was fluctuated in the case of $M$. obstructa where the enzyme activity was increased from $3.59 \mathrm{u} / \mathrm{l}$ after 1 day of the treatment and elevated to 20.47 after 3 days then, it decreased to $11.33 \mathrm{u} / \mathrm{l}$ but still above the normal activity for control. Concerning the effect of thiamethoxam formulation treatment, acid phosphatase was close to control where it was $3.38 \mathrm{u} / 1$ and 3.07 after 1 and 3 days of treatment respectively, but it increased to 8.27 u/l after 7 days for E. vermiculata. Regarding $M$. obstructa, the thiamethoxam formulation treatment decreased the enzyme activity to $67 \%$ after the $1^{\text {st }}$ day of the treatment and it caused acute elevation in the enzyme activity to $192 \%$ and $308 \%$ after 3 and 7 days after treatment of control, respectively.

Gradually, the enzyme activity was increased after spinosad formulation treatment in the case of E. vermiculata from 3.89 for the control to 5.39, 6.48 and $9.59 \mathrm{u} / 1$ after 1,3 and 7 days of the treatment, consecutively. It fluctuated in the case of M. obstructa where the enzyme activity unchanged after 1 day of administration control $(3.59 \mathrm{u} / \mathrm{l})$ the activity was decreased to $2.27 \mathrm{u} / \mathrm{l}$ after 3 days. In contrast, the compound caused a higher increase in the enzyme activity up to $10.39 \mathrm{u} / \mathrm{l}$ after 7 days of the treatment. Tannic acid treatment caused on increase in the enzyme activity of $E$. vermiculata and $M$. obstructa where it increased the enzyme activity from 3.89 to $5.05,5.72 \mathrm{u} / 1$ and from 3.59 to $6.37 \mathrm{u} / 1$ after 1 and 3 days of treatment for E. vermiculata and $M$. obstructa, consecutively. But, it decreased after 7 days of treatment to 4.69 and 3.99 for $E$. vermiculata and $M$. obstructa, respectively.

From the previous results in Tables (1\& 2) it is clear that the methomyl formulation treatment was the most effective compound on ALP activity in both snail species followed by tannic acid, spinosad, L- cyhalothrin formulation treatment and thiamethoxam formulation treatment, while, methomyl came in the last rank in its effect on the ACP activity in both snail species. Spinosad was the most effective compound followed by thiamethoxam, tannic acid and L- cyhalothrin in the case of $E$. vermiculata. Concerning $M$. obstructa, Lcyhalothrin was the best compound followed by thiamethoxam, spinosad and tannic acid. The differentiation of the activity of ALP and ACP may be referred to diffusion of these enzymes from the intracellular sites due to the damage caused by the pesticides on the sub cellular level. Alkaline and acid phosphatases are expressed in constant pattern and help to identify the different zones of the adult shell forming tissue (Maxen et al., 2003). The present results showed that the two snail species were similar in the susceptibility to the treatment with the five compounds in case of ALP while they differed in response to ACP.

\subsection{Effect on total protein}

Plasma proteins serve as a source for rapid replacement of tissue proteins during tissue depletions, as buffers in acid base balance and as transporters for the constituents of the blood, such as lipid, vitamins, hormones, iron, copper and certain enzymes (Warnick and Carter, 1972).

The data in Table (3) showed the effect of the tested compounds on the total protein in both snail species. The results indicated that no effect occurred with methomyl formulation treatment after one day, while it caused an increase in total protein content after 3 and 7 days to reach $126 \%$ and $280 \%$ respectively, of the control for $E$. vermiculata. Adverse effect was observed in the case of $M$. obstructa where methomyl formulation treatment increased the total protein from 0.71 to 1.20 and $2.17 \mathrm{~g} / \mathrm{dl}$ after 1and 3 days of the treatment, while it was decreased to 0.59 after 7 days of treatment. L- cyhalothrin formulation treatment increased the total protein value from $0.56 \mathrm{~g} / \mathrm{dl}$ in the control to 1.17 and $1.19 \mathrm{~g} / \mathrm{dl}$ after 1 and 3 days of the treatment while it decreased to 0.73 after 7 days of treatment for E. vermiculata. The response of total protein content was similar in Lcyhalothrin formulation treatment in $M$. obstructa but it still increased, where the total protein content increased to $156 \%, 161 \%$ and $241 \%$ of the control after 1,3 and 7 days of treatment. Thiamethoxam formulation treatment caused fluctuated response in the total protein level in E. vermiculata where it increased from $0.56 \mathrm{~g} / \mathrm{dl}$ in control to $1.63 \mathrm{~g} / \mathrm{dl}$ after 1 day of administration then it decreased to 0.74 after 3 days of treatment, but after 7 days of the treatment it elevated again to $2.00 \mathrm{~g} / \mathrm{dl}$. Regarding $M$. obstructa, total protein content increased after 1 day of the treatment from 0.71 $\mathrm{g} / \mathrm{dl}$ in the control to $1.48 \mathrm{~g} / \mathrm{dl}$, and then decreased to 0.66 and $0.23 \mathrm{~g} / \mathrm{dl}$ after 3 and 7 the days of the treatment, respectively. Spinosad raised total protein from $0.56 \mathrm{~g} / \mathrm{dl}$ to $0.66,0.90$ and $0.29 \mathrm{~g} / \mathrm{dl}$ after 1,3 and 7 days of administration, respectively for E. vermiculata. 
In the case of M. obstructa spinosad formulation treatment increased total protein level gradually from $0.71 \mathrm{~g} / \mathrm{dl}$ to 0.92 and $1.14 \mathrm{~g} / \mathrm{dl}$ after 1 and 3 days of treatment, while it induced it to 0.52 after 7 days of treatment. Total protein increased from $0.56 \mathrm{~g} / \mathrm{dl}$ to 1.49 and $2.59 \mathrm{~g} / \mathrm{dl}$ after 1 and 3 days of administration then it decreased to 1.15 $\mathrm{g} / \mathrm{dl}$ after 7 days of treatment with tannic acid for E. vermiculata. Adverse effect was observed in case of $M$. obstructa, where tannic acid treatment reduced the total protein content from $0.71 \mathrm{~g} / \mathrm{dl}$ in the control to $0.54 \mathrm{~g} / \mathrm{dl}$ then it increased to 1.52 and $2.19 \mathrm{~g} / \mathrm{dl}$ after 3 and 7 days of treatment, respectively.
Concerning L- cyhalothrin formulation compound, it had a fluctuating effect on total lipid in E. vermiculata, where it reduced from $6.96 \mathrm{~g} / \mathrm{dl}$ to $1.15 \mathrm{~g} / \mathrm{dl}$ after 1day of treatment, then increased to $4.18 \mathrm{~g} / \mathrm{dl}$ after 3 days but it decreased again to $2.77 \mathrm{~g} / \mathrm{dl}$ after 7 days of the treatment. In the case of M. obstructa total lipid level decreased after 1 day of treatment from $4.73 \mathrm{~g} / \mathrm{dl}$ to $1.17 \mathrm{~g} / \mathrm{dl}$ then it increased to 3.34 and $5.01 \mathrm{~g} / \mathrm{dl}$ after 3 and 7 days, consecutively. The response of the total lipid content to thiamethoxam formulation compound was similar in both snail species where it reduced from $6.96 \mathrm{~g} / \mathrm{dl}$ for control to $1.90 \mathrm{~g} / \mathrm{dl}$ for $E$.

Table (3): Effect of $\mathrm{LC}_{50}(\mathrm{mg} / \mathrm{kg})$ of various compounds used as bait on the total protein (g/dl) in two land snail species.

\begin{tabular}{|c|c|c|c|c|c|c|c|c|}
\hline \multirow{3}{*}{ Compounds } & \multicolumn{4}{|c|}{ Eobania vermiculata } & \multicolumn{4}{|c|}{ Monacha obstructa } \\
\hline & \multicolumn{4}{|c|}{ Periods after treatment (days) } & \multicolumn{4}{|c|}{ Periods after treatment (days) } \\
\hline & $\mathbf{0}$ & 1 & 3 & 7 & $\mathbf{0}$ & 1 & 3 & 7 \\
\hline Methomyl & $0.56 \pm 0.01$ & $0.53 \pm 0.03$ & $0.71 \pm 0.1$ & $1.57 \pm 0.07$ & $0.71 \pm 0.01$ & $1.20 \pm 0.2$ & $2.17 \pm 0.1$ & $0.59 \pm 0.15$ \\
\hline L- cyhalothrin & $0.56 \pm 0.01$ & $1.17 \pm 0.2$ & $1.19 \pm 0.2$ & $0.73 \pm 0.02$ & $0.71 \pm 0.01$ & $1.11 \pm 0.10$ & $1.14 \pm 0.1$ & $1.71 \pm 0.16$ \\
\hline Thiamethoxam & $0.56 \pm 0.01$ & $1.63 \pm 0.1$ & $0.74 \pm 0.06$ & $2.00 \pm 0.32$ & $0.71 \pm 0.01$ & $1.48 \pm 0.01$ & $0.66 \pm 0.05$ & $0.23 \pm 0.12$ \\
\hline Spinosad & $0.56 \pm 0.01$ & $0.66 \pm 0.01$ & $0.90 \pm 0.00$ & $2.29 \pm 0.4$ & $0.71 \pm 0.01$ & $0.92 \pm 0.04$ & $1.14 \pm 0.03$ & $0.52 \pm 0.1$ \\
\hline Tannic acid & $0.56 \pm 0.01$ & $1.49 \pm 0.05$ & $2.59 \pm 0.01$ & $1.15 \pm 0.2$ & $0.71 \pm 0.01$ & $0.54 \pm 0.09$ & $1.52 \pm 0.2$ & $2.19 \pm 0.1$ \\
\hline LSD & 0.02 & 0.16 & 0.23 & 0.39 & 0.02 & 0.19 & 0.17 & 0.16 \\
\hline
\end{tabular}

The pervious result from Table (3) proved that methomyl formulation exhibited the most effective one on the total protein content in $E$. vermiculata, while tannic acid played the same role in the case of $M$. obstructa. These results disagreed with Khidr et al., (2011) who found that thyophyline and furosemide compounds decreased the level of total protein in $M$. obstructa.

\section{4. Effect of total lipid}

Lipids play extremely important roles in the normal function of a cell. Not only do lipids serve as highly reduced storage form of energy, but they also play an intimate role in the structure of cell membranes and the organelles found in the cell (Warnick and Carter, 1972).

The data summarized in Table (4) showed the effect of the tested compounds on the total lipid. The results indicated that methomyl formulation compound reduced the total lipid content from 6.96 to 0.69 after 1 day of the treatment, and then it increased to $3.09 \mathrm{~g} / \mathrm{dl}$ after 3 days of the treatment while it reduced again to $2.93 \mathrm{~g} / \mathrm{dl}$ after 7 days of the treatment but still under the control level for E. vermiculata. Also the same compound reduced the total lipid level to $62 \%$, $36 \%$ and $13 \%$ of control after 1, 3 and 7 days of administration, respectively for $M$. obstructa. vermiculata and from $4.73 \mathrm{~g} / \mathrm{dl}$ for control to $1.17 \mathrm{~g} / \mathrm{dl}$ for $M$. obstructa after 1 day of treatment, respectively. Total lipid content increased to 1.9 and 3.18 for E. vermiculata, 2.89 and $3.58 \mathrm{~g} / \mathrm{dl}$ for $M$. obstructa after 3 and 7 days of administration, consecutively. Spinosad formulation treatment caused gradual decreases in total lipid level to $33 \%, 18 \%$ and $7 \%$ of the control after 1,3 and 7 days of treatment, respectively in case of $E$. vermiculata, while reduced the level of total lipid to $16 \%$ after one day of treatment for $M$. obstructa, then, increased to $31 \%$ and $45 \%$ after 3 and 7 day after treatment, respectively but it still under level of control. Tannic acid reduced the total lipid level from 6.96 for control to $3.63 \mathrm{~g} / \mathrm{dl}$ after one day of treatment while increased to $7.15 \mathrm{~g} / \mathrm{dl}$ after 3 days of treatment then it decreased again to $3.40 \mathrm{~g} / \mathrm{dl}$ after 7 days after administration of E. vermiculata. Regarding $M$. obstructa, tannic acid treatment decreased the level of total lipid content from 4.73 for control to $1.07 \mathrm{~g} / \mathrm{dl}$ after 1 day of treatment, and then it increased to 2.26 and $3.66 \mathrm{~g} / \mathrm{dl}$ after 3 and 7 days of treatment, respectively.

From the previous results in Tables (3 and 4) it can be concluded that E. vermiculata was more susceptible to methomyl and spinosad 
Table (4): Effect of $\mathrm{LC}_{50}(\mathrm{mg} / \mathrm{kg})$ of various compounds used as bait on the total lipid (g/l) in two land snail species.

\begin{tabular}{|l|c|c|c|c|c|c|c|c|}
\hline \multirow{3}{*}{ Compounds } & \multicolumn{4}{|c|}{ Eobania vermiculata } & \multicolumn{4}{c|}{ Monacha obstructa } \\
\cline { 2 - 9 } & \multicolumn{3}{|c|}{ Periods after treatment (days) } & \multicolumn{3}{c|}{ Periods after treatment (days) } \\
\cline { 2 - 9 } & $\mathbf{0}$ & $\mathbf{1}$ & $\mathbf{3}$ & $\mathbf{7}$ & $\mathbf{0}$ & $\mathbf{1}$ & $\mathbf{3}$ & $\mathbf{7}$ \\
\hline Methomyl & $\mathbf{6 . 9 6} \pm \mathbf{0 . 1}$ & $\mathbf{0 . 6 9} \pm \mathbf{1 . 2}$ & $\mathbf{3 . 0 9} \pm \mathbf{0 . 2}$ & $\mathbf{2 . 9 3} \pm \mathbf{0 . 1}$ & $\mathbf{4 . 7 3} \pm \mathbf{0 . 1}$ & $\mathbf{2 . 9 4} \pm \mathbf{0 . 1 2}$ & $\mathbf{1 . 6 8} \pm \mathbf{0 . 1 9}$ & $\mathbf{0 . 6 1} \pm \mathbf{0 . 6}$ \\
\hline L- cyhalothrin & $\mathbf{6 . 9 6} \pm \mathbf{0 . 1}$ & $\mathbf{1 . 1 5} \pm \mathbf{0 . 2}$ & $\mathbf{4 . 1 8} \pm \mathbf{0 . 0}$ & $\mathbf{2 . 7 7} \pm \mathbf{0 . 0 3}$ & $\mathbf{4 . 7 3} \pm \mathbf{0 . 1}$ & $\mathbf{1 . 1 7} \pm \mathbf{1 . 9}$ & $\mathbf{3 . 3 4} \pm \mathbf{0 . 0 4}$ & $\mathbf{5 . 0 1} \pm \mathbf{0 . 8}$ \\
\hline Thiamethoxam & $\mathbf{6 . 9 6} \pm \mathbf{0 . 1}$ & $\mathbf{1 . 9 0} \pm \mathbf{0 . 0 2}$ & $\mathbf{3 . 1 8} \pm \mathbf{0 . 0 2}$ & $\mathbf{4 . 9 4} \pm \mathbf{0 . 0 5}$ & $\mathbf{4 . 7 3} \pm \mathbf{0 . 1}$ & $\mathbf{1 . 1 7} \pm \mathbf{1 . 0}$ & $\mathbf{2 . 8 4} \pm \mathbf{0 . 0 4}$ & $\mathbf{3 . 5 8} \pm \mathbf{0 . 0 8}$ \\
\hline Spinosad & $\mathbf{6 . 9 6} \pm \mathbf{0 . 1}$ & $\mathbf{2 . 2 7} \pm \mathbf{1 . 0}$ & $\mathbf{1 . 2 4} \pm \mathbf{0 . 1}$ & $\mathbf{0 . 4 9} \pm \mathbf{0 . 2}$ & $\mathbf{4 . 7 3} \pm \mathbf{0 . 1}$ & $\mathbf{0 . 7 8} \pm \mathbf{0 . 0 5}$ & $\mathbf{1 . 4 7} \pm \mathbf{0 . 7}$ & $\mathbf{2 . 1 1} \pm \mathbf{0 . 5}$ \\
\hline Tannic acid & $\mathbf{6 . 9 6} \pm \mathbf{0 . 1}$ & $\mathbf{3 . 6 3} \pm \mathbf{0 . 3}$ & $\mathbf{7 . 1 5} \pm \mathbf{0 . 4}$ & $\mathbf{3 . 4 0} \pm \mathbf{0 . 6}$ & $\mathbf{4 . 7 3} \pm \mathbf{0 . 1}$ & $\mathbf{1 . 0 7} \pm \mathbf{0 . 3}$ & $\mathbf{2 . 2 6} \pm \mathbf{0 . 0 3}$ & $\mathbf{3 . 6 6} \pm \mathbf{0 . 1 1}$ \\
\hline LSD & $\mathbf{0 . 0 2}$ & $\mathbf{0 . 3 9}$ & $\mathbf{0 . 2 3}$ & $\mathbf{0 . 4 6}$ & $\mathbf{0 . 0 2}$ & $\mathbf{0 . 3 2}$ & $\mathbf{0 . 3 7}$ & $\mathbf{0 . 3 5}$ \\
\hline
\end{tabular}

formulations than the other compounds in total protein and lipid. While M. obstructa differed in response to different compounds where it was most susceptible to tannic acid treatment in total protein but it resembled E. vermiculata in the response of total lipid in methomyl and spinosad treatments. The fluctuation in the level of total protein and total lipid may be attributed to the major organ synthesis was damaged causing an alteration of its production capacity. The fluctuation in the level of protein and total lipid may be attributed to the imbalance between the rate of biosynthesis and degradation process occurred by high enzyme stress (Saxena et al., 1989 and Khater et al., 1990).

\section{5. Effect on cholesterol}

Cholesterol supplies affect the growth, reproduction and survival of land snails (Wacker, 2005).

Data in Table (5) showed the response of cholesterol to the different compounds against the two land snail species. The results cleared that methomyl formulation reduced cholesterol level to $79 \%, 78 \%$ of the control after 1 and 3 days of treatment, then the it increased to $80 \%$ after 7 days but less than normal level of the control against $E$. vermiculata. The same compound caused a gradual decrease in cholesterol level in M. obstructa to $83 \%, 78 \%$ and $68 \%$ of control after 1,3 and 7 days of treatment. Also, L- cyhalothrin compound reduced the cholesterol level in E. vermiculata from 255.0 to 210.9 and $197.1 \mathrm{mg} / \mathrm{dl}$ after 1 and 3 days of the treatment, then increased again to $200.5 \mathrm{mg} / \mathrm{dl}$ after 7 days of the treatment but it was still less than the level of the control. Lcyhalothrin formulation decreased cholesterol level of $M$. obstructa from $242.5 \mathrm{mg} / \mathrm{dl}$ in control to $198.0 \mathrm{mg} / \mathrm{dl}$ after 1 day of administration but it gradually increased to 203.7 and 204.7 after 3 and 7 days of treatment, consecutively. Thiamethoxam formulation declined the cholesterol level in E. vermiculata from $255.0 \mathrm{mg} / \mathrm{dl}$ to $202.1 \mathrm{mg} / \mathrm{dl}$ after 1 day of treatment then it increased gradually to 203.7 and $204.6 \mathrm{mg} / \mathrm{dl}$ after 3 and 7 days of administration, respectively. In the case of $M$. obstructa, thiamethoxam formulation decreased cholesterol level from $242.5 \mathrm{mg} / \mathrm{dl}$ of the control to $206.4 \mathrm{mg} / \mathrm{dl}$ after 1 day of treatment. After 3 days thiamethoxam formulation increased cholesterol level to 205.4 but it declined again to $201.7 \mathrm{mg} / \mathrm{dl}$ after 7 days of administration. For E. vermiculata cholesterol level decreased from $255.0 \mathrm{mg} / \mathrm{dl}$ of control to $213.7 \mathrm{mg} / \mathrm{dl}$ after one day of treatment while increased to $214.0 \mathrm{mg} / \mathrm{dl}$ after 3 days of spinosad administration but it still stable at $214.0 \mathrm{mg} / \mathrm{dl}$. Also it decreased from 242.5 to $207.7 \mathrm{mg} / \mathrm{dl}$ after one day and increased to 211.2 and $215.7 \mathrm{mg} / \mathrm{dl}$ after 3 and 7 days of treatment, respectively, by the same compound. Concerning tannic acid, cholesterol level

Table (5): Effect of $\mathrm{LC}_{50}(\mathrm{mg} / \mathrm{kg})$ of various compounds used as bait on cholesterol (mg/dl) in two land snail species.

\begin{tabular}{|c|c|c|c|c|c|c|c|c|}
\hline \multirow{3}{*}{ Compounds } & \multicolumn{4}{|c|}{ Eobania vermiculata } & \multicolumn{4}{|c|}{ Monacha obstructa } \\
\hline & \multicolumn{4}{|c|}{ Periods after treatment (days) } & \multicolumn{4}{|c|}{ Periods after treatment (days) } \\
\hline & $\mathbf{0}$ & 1 & 3 & 7 & $\mathbf{0}$ & 1 & 3 & 7 \\
\hline Methomyl & $255.0 \pm 0.02$ & $201.3 \pm 0.1$ & $202.3 \pm 0.7$ & $205.4 \pm 0.6$ & $242.5 \pm 3.0$ & $203.0 \pm 0.06$ & $186.7 \pm 1.2$ & $164.4 \pm 0.9$ \\
\hline L- cyhalothrin & $255.0 \pm 0.02$ & $210.9 \pm 1.9$ & $197.1 \pm 1.5$ & $200.5 \pm 0.05$ & $242.5 \pm 3.0$ & $198.0 \pm 0.1$ & $203.7 \pm 0.12$ & $204.7 \pm 1.0$ \\
\hline Thiamethoxam & $255.0 \pm 0.02$ & $202.1 \pm 2.02$ & $203.7 \pm 5.0$ & $204.6 \pm 1.8$ & $242.5 \pm 3.0$ & $206.4 \pm 0.5$ & $205.4 \pm 1.7$ & $201.7 \pm 2.1$ \\
\hline Spinosad & $255.0 \pm 0.02$ & $213.7 \pm 5.2$ & $214.0 \pm 4.1$ & $214.0 \pm 2.0$ & $242.5 \pm 3.0$ & $207.7 \pm 4.1$ & $211.2 \pm 0.5$ & $215.7 \pm 1.7$ \\
\hline Tannic acid & $255.0 \pm 0.02$ & $238.0 \pm 1.7$ & $414.8 \pm 6.3$ & $507.7 \pm 2.0$ & $242.5 \pm 3.0$ & $611.9 \pm 1.3$ & $519.0 \pm 0.46$ & $435.7 \pm 5.0$ \\
\hline LSD & 0.02 & 4.13 & 11.17 & 2.81 & 0.02 & 11.14 & 14.02 & 8.11 \\
\hline
\end{tabular}


reduced to $93 \%$ of control after 1 day of treatment then, severly increased to $163 \%$ and $199 \%$ happened after 3 and 7 days of administration consecutively, for E. vermiculata. for M. obstructa tannic acid caused severe increase in cholesterol level to $252 \%$ of control after 1 day of administration, then decreased to $214 \%$ and $180 \%$ after 3 and 7 days of treatment respectively, but it still up to the level of control.

Reviewing the aforementioned results we can observe that tannic acid treatment was the most effective compound against both snail species, followed by the formulation of L- cyhalothrin, methomyl, and thiamethoxam formulation treatment while spinosad formulation came in the last rank. The fluctuation betweens increase and decrease in cholesterol level could be due to the accumulation of pesticides in the cell of mantel which the major cell to product the shell of snails. Rizk and Faddah (1996) observed that bayluscide compound increased the level of cholesterol in Bimophalaria alaxandrina snail.

In conclusion from the results obtained from Tables (1-5) it is obvious that methomyl and tannic acid came in the first or the second rank of the effect on the tested biochemical parameters for the two species of snails. Both had strong effect on ALP and ACP enzymes activities and cholesterol content which are responsible to inhibit the production of shell that is very important for snail life. Kandil et al (2014) reported that acetylsalicylic acid exhibited the highest effect on ALP, ACP and cholesterol important for the synthesis of shell and mucous.

\section{REFERENCES}

Bergmeyer H. (1963). Methods of enzymatic analysis. Academic press In New York, USA, pp. 886.

COHORT SOFTWARE (2005). Costat program. 6. 311. (780 lihgthouse, Ave. PMB 320, Monterey, CA, USA).

Ellefson R. D. and Caraway W. T. (1976). Fundamentals of clinical chemistry. Ed. Titez NW, PP 506.

Eshra E. H. (2013). Survey and distribution of terrestrial snails in fruit orchards and ornamental plants at Alexandria and ElBehira Governorates, Egypt. Alexandria Science Exchange Journal. 34 (2): 242248.

Godan D. (1983). Pest Slugs and Snails (biology and control) Springer Verlg Berkin Hidelberg. New York 345 pp.
Henry R. J. (1964). Clinical Chemistry, Principles and Techniques. Harper and Row Publishers. New York USAPP. 181.

Hugon J. and Bogers M. (1966). Ultrastructural localization of alkaline phosphatase activity in the absorbing cells of the duodenum of mucous. J. Histochem. Cytochem., 14: 629-640.

Kandil M. A., El-Deeb H. I., Eweis E. A. and Mobarak S. A. (2007). Molluscicidal activity of binary mixtures of some pesticides with acetylsalicylic or tannic acids against the land snails Eobania vermiculata and Monacha obstructa. J. Egypt Ger. Soc. Zool., (53D): Invertebrate zool. and parasitol. (53D): 77- 87.

Kandil M. A., El-Deeb H.I., Eweis E.A., Gabr W. M. and Soha Mobarak A. (2014). Is acetylsalicylic acid has ability to disturb the physiological role of mucus gland of land snail species? J. Agric. Res. In press.

Khater A. A., El-Sheikh A. A., El-Sheamy M. K. and Hussein M. Z. (1990). Biochemical effects of lannate and larvin on Tilapia nilotica fingerlings. Egypt. J. Appl. Sci., 5(8): 227-235.

Khidr Fatma K., Abo- Hashem A. A. M., Keshta T. M. S. and Ismail Samah M. A. (2011). Some of Biochemical changes induced by thyophyline and furosemide in the land snail Monacha obstructa. J. Plant Prot. And Pathology, Mansoura Univ., 2 (4): 429- 437.

Kind P. R. N. and King E. J. (1954). Estimation of plasma phosphatase by determination of hydrolyzed phenol with amino antipyrine. J. Clin. Path., 7: 322-326.

Maxen J. C., Witten P. E., Finke D., Reelsen O., Rezagaoui M. and Becker W. (2003). A light and electron- microscopic study of enzymes in the embryonic shell- forming tissue of the fresh water snail, Biomphalaria glabrata. Invertebrate Biol., 122 (4): 313- 325.

Rizk M. and Faddah L. M. (1994). Effect of some factors on the level of certain biochemical parameters in Biomphalaria alexandrina snails. Egypt $\mathrm{J}$. of Bilharziasis.16 (1-2): 77-88.

Saxena P. K., Singh V. P., Kondal J. K. and Soni G. L. (1989). Effect of some pesticides on in vitro lipid and protein synthesis by the liver of the freshwater teleost, Channa punctatus (BL.). Environ. Pollut., 58: 273-276. 
Singh A. and Agarwal R. A. (1992). Toxicity of the latex of euphorbiales. Effect on acid and alkaline phosphatase of the snail Lymnaea acuminata. Biol. Agric. Hort. 8: 211-219.

Wacker A. (2005). Lipid in the food of terrestrial snail. Invertebrate reproduction and development, 47 (3): 205- 212.
Warnick S. L. and Carter J. E. (1972). Some findings in a study of workers occupationally exposed to pesticides. Arch. Environ. Health., 25: 267- 271.

Zollner N. and Kirsch K. (1962). Determination of Lipids (micro method) by means of sulphophosphoanilin reaction common to many natural lipids (all known plasma lipids). Z. Gas Exp. Med., 135: 545-561.

\title{
التأثير الكيموحيوى لمركبات مختلفة على نوعين من القواقع الارضية: قوقع الخطوط الثيكو لاتيه وقوقع البرسيم الزجاجى لئح
}

سها عبدالله مبارك

معهة بحوث وقاية النباتات - مركز البحوث الزر اعبة - الجيزة- مصر.

\begin{abstract}
ملخص

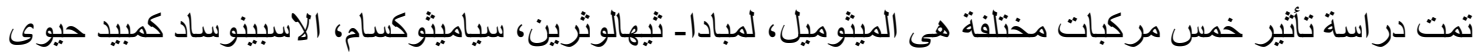

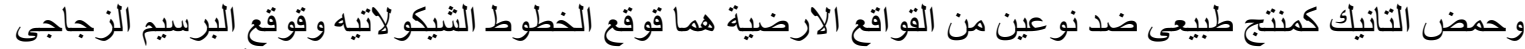

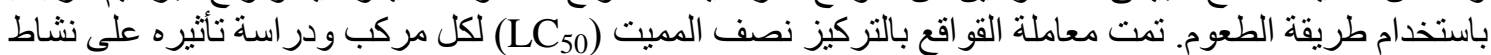

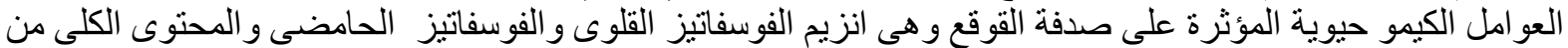

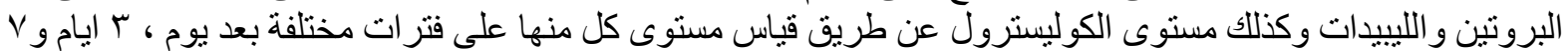

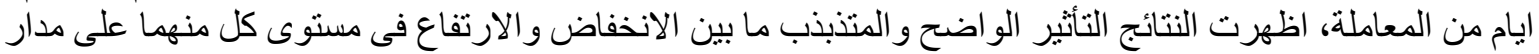

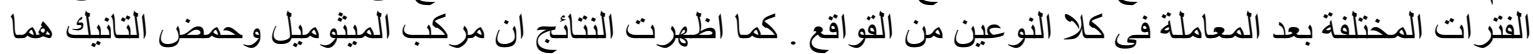

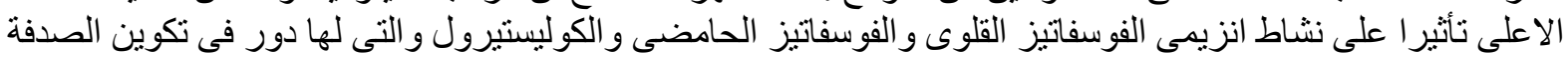

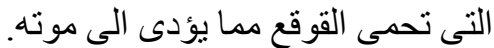

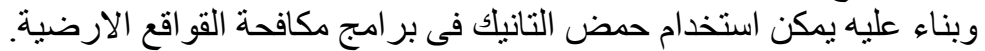

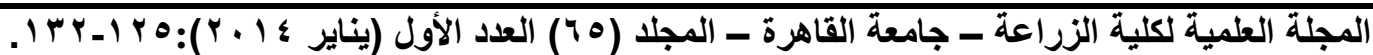

